\title{
Principles of designing interpretable optogenetic behavior experiments
}

\author{
Brian D. Allen, ${ }^{1,2,3,4}$ Annabelle C. Singer, ${ }^{1,2,3,4}$ and Edward S. Boyden ${ }^{1,2,3}$ \\ ${ }^{1}$ Media Lab; ${ }^{2}$ McGovern Institute for Brain Research; ${ }^{3}$ Departments of Biological Engineering and Brain and Cognitive Sciences, \\ Massachusetts Institute of Technology, Cambridge, Massachusetts 02139, USA
}

\begin{abstract}
Over the last decade, there has been much excitement about the use of optogenetic tools to test whether specific cells, regions, and projection pathways are necessary or sufficient for initiating, sustaining, or altering behavior. However, the use of such tools can result in side effects that can complicate experimental design or interpretation. The presence of optogenetic proteins in cells, the effects of heat and light, and the activity of specific ions conducted by optogenetic proteins can result in cellular side effects. At the network level, activation or silencing of defined neural populations can alter the physiology of local or distant circuits, sometimes in undesired ways. We discuss how, in order to design interpretable behavioral experiments using optogenetics, one can understand, and control for, these potential confounds.
\end{abstract}

Optogenetic tools allow for the precise control of the electrical activity of genetically targeted neurons by transporting specific ions into or out of cells in response to light. These tools are light-sensitive proteins known as opsins, which are seven-transmembrane proteins that play photosensory or metabolic roles in species throughout the tree of life (Boyden 2011). These opsins respond to light either by pumping ions into or out of cells (e.g., halorhodopsins pump chloride ions into archaea in response to light; bacteriorhodopsins and archaerhodopsins pump protons out of archaea in response to light), or by opening an ion channel (e.g., channelrhodopsins let cations such as sodium, protons, and calcium into eyespots of algae). By expressing these molecules in specific neurons, regions, or projection pathways, the targeted circuit elements can then be silenced or activated in response to light. Halorhodopsins and archaerhodopsins are commonly used for optical silencing of neural activity with light (Han and Boyden 2007; Zhang et al. 2007a; Chow et al. 2010; Gradinaru et al. 2010; Han et al. 2011; Chuong et al. 2014). Channelrhodopsins are commonly used for optical activation of neural activity with light (Boyden et al. 2005; Nagel et al. 2005; Yizhar et al. 2011; Klapoetke et al. 2014).

These molecules have become widespread in neuroscience for the investigation of how specific neural circuit elements contribute to behavior, and are even being contemplated for therapeutic purposes (Chow and Boyden 2013). This popularity is in part because in mammals the light-absorbing component of optogenetic tools (the chromophore all-trans retinal) is naturally present in the brain and body (Ishizuka et al. 2006). To the end of designing and interpreting behavior experiments using optogenetics, it is important to understand the side effects that these optogenetic proteins can cause in living cells, as well as the effects of heat and light on neural functions, and the biochemical activity of specific ions transported by optogenetic proteins. Additionally, activation or silencing of defined neural populations can result in network-level side effects, for example, through synaptically mediated activation of unanticipated downstream neurons. Here we discuss how these considerations can inform the design

\footnotetext{
${ }^{4}$ These authors contributed equally to this work. Corresponding author: esb@media.mit.edu

Article is online at http://www.learnmem.org/cgi/doi/10.1101/lm.038026.114. Freely available online through the Learning \& Memory Open Access option.
}

and interpretation of behavioral experiments that incorporate optogenetics as a tool.

\section{Cell-autonomous side effects}

\section{Protein expression}

Expressing a protein in a cell can result in side effects in that cell. High levels of expression of any protein can, in principle, adversely affect cell health, and even result in cell death (Liu et al. 1999; Klein et al. 2006). Unfortunately expression levels are difficult to accurately characterize in vivo and thus the exact relationship between expression level and toxicity is often not well understood. Determining whether or not a given level of expression (e.g., as governed by gene dosage, promoter choice, and duration of expression) causes toxicity or other side effects is complicated because such effects may depend on factors including species, brain region, cell type, and age of the animal. High expression of a protein may alter electrophysiology as well as cell health: in studies examining the effects of expressing opsins at high levels in mammalian human embryonic kidney 293 (HEK293) cells in vitro, changes were reported in the capacitance of the membrane (Zimmermann et al. 2008). Drosophila have expressed opsins under 20 copies of a conditional enhancer the upstream activating sequence (UAS), which may support a recent report of high light sensitivity of neurons in such flies for optogenetic activation (Klapoetke et al. 2014). As another example, the Natronomonas pharaonis halorhodopsin first assessed in neurons as an optogenetic silencer candidate (Han and Boyden 2007; Zhang et al. 2007a) has been efficacious in multiple Caenorhabditis elegans studies (e.g., Wen et al. 2012), but in mammals appeared to form aggregates when expressed at high levels in cortical neurons (Zhang et al. 2007a; Gradinaru et al. 2008; Zhao et al. 2008). As a result, other silencers have grown in popularity, including the archaerhodopsin-class silencers (Chow et al. 2010), as well as halorhodopsins with appended trafficking-enhancement sequences (Gradinaru et al. 2010; Chuong et al. 2014). Curiously, one transgenic mouse has been created with the original $N$. pharaonis halorhodopsin in the hypocretin/orexin neurons of the mouse

(C) 2015 Allen et al. This article, published in Learning \& Memory, is available
under a Creative Commons License (Attribution 4.0 International), as described at http://creativecommons.org/licenses/by/4.0/. 
hypothalamus, and no abnormal morphology nor changes in cell electrical properties were noted, despite expression levels strong enough to elicit sleep upon light delivery to these cells (Tsunematsu et al. 2011). As another example, newborn neurons in the adult mouse hippocampus were reported to increase channelrhodopsin expression slowly over 3 mo following neuronal differentiation, a relatively slow timecourse (Toni et al. 2008). Thus, it is possible that some cells, under specific gene expression conditions, may express optogenetic tools better or worse than other cells, even within the same species.

Opsins are often fused to fluorescent proteins to facilitate visualization in opsin-expressing cells. The type of fluorescent protein used can modulate opsin function. For example, in zebrafish, the unaltered $N$. pharaonis halorhodopsin appeared to clump when expressed with the fluorophore mCherry, more than it did when fused to the fluorophore YFP (Arrenberg et al. 2009). This differential effect may have persisted even after appending trafficking sequences (e.g., compare Fig. 1B and Supplemental Fig. S1B of the aforementioned citation). Clumping of a channelrhodopsin fused to mCherry also was apparent in Figure $2 \mathrm{E}$ of (Atasoy et al. 2008), suggesting that mCherry may not be an ideal fluorophore for opsin usage. Similarly, transgenic animals expressing channelrhodopsin-2 fused to YFP exhibited greater optical excitability than did those with channelrhodopsin-2 fused to tdTomato (Madisen et al. 2012).

How then does one achieve efficacious and safe expression of an optogenetic tool in a cell type of interest? In mammals, viruses expressing opsins under cell-specific promoters in principle are useful, but many cell-specific promoters are not small enough to fit into a virus. Some commonly used promoters can target neurons (e.g., synapsin-1), or simply express pancellularly (e.g., CAG, $\mathrm{EF} 1 \alpha$ ) (Kügler et al. 2003; Dittgen et al. 2004; Betley and Sternson 2011), when used in adeno-associated virus (AAV) or lentivirus, two popular methods of viral gene delivery into the mammalian brain. Complicating attempts to target expression, viruses themselves can have various tropisms, i.e., they can infect some cell types preferentially over others. For example, AAV serotype $2 / 1$ has been reported to preferentially target inhibitory neurons, whereas lentivirus pseudotyped with a glycoprotein from the vesicular stomatitis virus (VSVg) has been reported to preferentially target excitatory neurons (Nathanson et al. 2009). Promoter-virus combinations may thus need to be optimized jointly in order to guarantee a high level of specificity.

Accordingly, many groups working with mammals have turned to transgenic mice, which can be equipped with large promoters inserted, for example, in bacterial artificial chromosome (BAC) form, to enable expression of an opsin in a specific cell class (Arenkiel et al. 2007; Borgius et al. 2010; Zhao et al. 2011). However, in addition to targeting gene expression to specific cells, such large promoters can, in principle, contain DNA sequences that modulate opsin or cellular functions. For example, the choline acetyltransferase (ChAT) gene is expressed in cholinergic neurons, and its promoter has been used to make transgenic mice expressing channelrhodopsin-2 in cholinergic neurons. This promoter, however, contains an entire gene which happens to encode for the vesicular acetylcholine transporter (VAChT), and mice thus created exhibit altered cholinergic tone and concomitant changes in behavior (Kolisnyk et al. 2013).

A hybrid method achieves targeted gene expression by taking advantage of the many hundreds of mice that express Cre recombinase transgenically under a specific promoter (via BAC transgenesis, knock-in, or other methods; see databases by the GENSAT project (Gong et al. 2003, 2007; web site: www.gensat .org; www.ncbi.nlm.nih.gov/projects/gensat) or Allen Mouse Brain Connectivity Atlas (Oh et al. 2014; web site: 2014 Allen Institute for Brain Science. Allen Mouse Brain Connectivity
Atlas [Internet]. Available from: http://connectivity.brain-map .org/). The opsin is then delivered via a virus that infects broad sets of cells but whose gene expression is gated by Cre recombinase expression in the target cells. The gene of interest is flanked by lox sites organized so that Cre causes the deletion of a stop sequence or reversal of the gene sequence from a backwardto-forward direction (Atasoy et al. 2008; Kuhlman and Huang 2008; Sohal et al. 2009). Alternatively, such Cre mice can be bred with transgenic mice whose genomes code for opsins in similar Cre-dependent expression cassettes, so that offspring selectively express the opsin in defined sets of cells (Madisen et al. 2012). When using such mice it is important to check for "leaky" or non-Cre-dependent expression. For instance transient expression of Cre early in life could cause recombination that will then persist throughout life, causing enduring, and perhaps undesired, opsin expression in those cells (Betz et al. 1996; Metzger and Feil 1999; Zhuang et al. 2005).

In Drosophila (Schroll et al. 2006; Zhang et al. 2007b) and zebrafish (Douglass et al. 2008; Baier and Scott 2009), the GAL4/ UAS expression system is commonly used because animals expressing GAL4 under a promoter can be crossed with animals with an opsin behind a UAS, enabling targeted expression via pairwise breeding. Of course, transgenic animals with cassettes bearing opsins under specific promoters can also be directly generated, e.g., in C. elegans (Nagel et al. 2005). Other expression systems-for instance the Tet off system (Zhu et al. 2009; Bundschuh et al. 2012), the Cre/lox (see above) or FLP/FRT systems (Schmitt et al. 2012; Fenno et al. 2014)—can also be used in many different species.

Optimizing the expression of opsins in the targeted cell type early in an experiment can save time and effort later on. When viruses are used, it is helpful to determine which virus produces optimal expression (in terms of volume of tissue infected, density of infected cells, and amplitude of expression in cells) empirically; one can obtain aliquots of viruses with many different promoters and serotypes (i.e., from a core facility), and test them in parallel in mice, evaluating the outcome using histology. For example, we often try multiple AAV serotypes, e.g., 8 and 5, as well as 2, 9, and dj (if desired), varying the concentration by diluting virus down from its source concentration (e.g., $5 \times, 10 \times$, etc. dilutions from the original concentration), in order to identify a viral dose that maximizes the number of target neurons infected, without resulting in overexpression within individual cells. When using viruses to infect cells, the proportion of target cells that express the opsin will vary from animal to animal. This variability can be harnessed for scientific discovery by using it to create a dose-response curve in which the proportion of cells infected is the dose (e.g., Aponte et al. 2011; Kim et al. 2012). Strategies to achieve a high proportion of opsin-expressing cells will vary depending on the opsin, cell type, and species; therefore we recommend trying multiple approaches in parallel as described above. Physiological validation is important, ideally in the context of the actual experiment. For example, in a study in zebrafish cardiology, investigators observed that halorhodopsin expression in cardiomyocytes varied among transgenic zebrafish. They screened for animals with strongest light responses, which occurred in about a quarter of the fish (Arrenberg et al. 2010), which facilitated later experimentation.

The time that opsins take to express can vary depending on the species, age, cell type, mode of delivery, or cell compartment desired for photoperturbation. Thus, empirical determination of expression at different time points after initiation of expression may be of use. For example, it is not uncommon to perform experiments with mice 4 wk after viral delivery (e.g., by AAV), but many groups wait six or more weeks for opsin expression to reach distal axons of an infected cell (Ciocchi et al. 2010; Witten et al. 2010; 
Tye et al. 2011; Felix-Ortiz et al. 2013; Kim et al. 2013), though in cholinergic neurons virally infected at a young age, just 3 wk were reported to be effective for axonal expression (Kalmbach et al. 2012).

Given the potential for side effects of expressing opsins in cells, assessing toxicity may be of utility for specific scientific or preclinical questions, and can be aided by analyzing cells with respect to accepted criteria or markers of toxicity for the cell type of interest (Gradinaru et al. 2007; Han et al. 2009; Doroudchi et al. 2011; Miyashita et al. 2013). Experiments to assess toxicity ideally should insure that an opsin (or its attached fluorophore) has not adversely altered gross cell morphology or function, and may include histology, electrical recordings, molecular profiling, and other strategies. To address "leaky" expression of opsins, e.g., in cell types other than the one targeted, one can assess whether the levels of expression in nontargeted cells are meaningful, for instance whether the undesired cells express significant amounts of protein, or respond to light stimulation (Madisen et al. 2012). Experiment design should enable comparison of results obtained from both opsin-infected and control cells or animals. Controls include tissue infected with viruses bearing a fluorescent protein with no opsin fused (though such viruses will express cytosolically, rather than near the membrane as if anchored to an opsin), or potentially an opsin with residues mutated to prevent light-activation but with otherwise normal folding and trafficking.

\section{Heat and light}

Light, when absorbed by brain tissue, results in heating. The exact degree of heating for a given wavelength, duration, and power of light delivered depends on intrinsic brain properties, such as the local volume and rate of blood flow, as well as extrinsic properties, such as whether the brain is exposed to ambient temperatures after skull removal, which may encourage cooling (Kalmbach and Waters 2012). Some reports have indicated that powers of light commonly used in optogenetics may result in heating of a fraction of a degree or more, even with modest pulse durations and frequencies (Elias et al. 1987; Christie et al. 2013). Heating of cells has been shown to increase activity of specific kinds of neurons in multiple species (Moser et al. 1993; Long and Fee 2008), although neurons equipped with different channels or receptors may undergo different kinds of changes in response to heating. Light has been shown to result in artifactual fMRI signals in the BOLD response, when delivered to the brain (Desai et al. 2011; Christie et al. 2013), perhaps due to heating.

Light can also have nonthermal effects on cells: light-sensitive molecular pathways (opsin-mediated or otherwise) naturally found in optogenetically targeted cells or their neighbors could potentially cause undesired effects. For example, in Drosophila and C. elegans, light has been shown to drive cellular signaling via newly discovered signaling pathways (Edwards et al. 2008; Liu et al. 2010; Xiang et al. 2010). In C. elegans, reactive oxygen species driven by illumination have been implicated in this signaling (Bhatla and Horvitz 2015). Light-receptive molecules have been reported to exist in brains of the vertebrates (Okano et al. 1994; Blackshaw and Snyder 1999; Koyanagi et al. 2013). Light may have other effects on experiments, such as causing photoelectric artifacts on neural recording electrodes (Ayling et al. 2009; Han et al. 2009). Light may also distract the animal, perhaps eliciting increased locomotion (Godsil and Fanselow 2004) or encouraging the use of a visual distractor to mask the optogenetic stimulus (Huber et al. 2008). Choosing wavelengths of light that the animal cannot see, or is less responsive to, may ameliorate this (Inada et al. 2011; Klapoetke et al. 2014), as can usage of an- imals that are engineered to be insensitive to light (Kocabas et al. 2012).

To address the potential effects of light and heat, optogenetic experimental design should include controls in which light is delivered in the same manner as the experimental condition but on tissue that expresses a control protein that does not result in neurons responding to light (e.g., with a fluorescent protein, as described above). As red light-sensitive molecules come into use (Chuong et al. 2014; Klapoetke et al. 2014), in some species and contexts red light will incur less tissue absorption than blue or green, and thus incur less heating. If only a small section of tissue needs to be illuminated, the use of smaller light sources, lower light intensities, and/or shielding (e.g., in the form of beveled guide cannulas) could be used to limit light delivery to the targeted volume (Zorzos et al. 2010; Tye et al. 2011). Alternately, if a large area must be illuminated, strategies that can reduce unwanted heating include using larger fibers (Goshen et al. 2011), fiber tips or lenses that spread light, or multiple light sources (Bernstein and Boyden 2011). Finally, while optogenetic approaches are well suited to manipulate neural activity with millisecond precision, for long-duration experiments that do not require millisecond precision either switching opsins (e.g., step-function opsins [Berndt et al. 2009; Bamann et al. 2010; Yizhar et al. 2011]), or chemogenetic or pharmacogenetic approaches (i.e., using a heterologous receptor and a chemical agonist for that receptor [Shapiro et al. 2012]) might be well worth exploring.

Although not specific to optogenetics, the need for implants that go into the brain is also worth considering when designing an experiment. Devices to deliver light, like implanted optical fibers aimed at deep targets, can displace or damage brain tissue. This may be particularly crucial if regions overlying a region of interest are themselves involved in the behavior, or if scientific questions (e.g., development, dendritic spine plasticity, disease progression) are altered by the presence of an invasive element (Chuong et al. 2014). Recently developed opsins that are sensitive to red light (e.g., the channelrhodopsin ChrimsonR [Klapoetke et al. 2014] and the halorhodopsin Jaws [Chuong et al. 2014]) can alleviate these issues by reducing reliance upon implanted light sources. Because red light can more readily travel through brain tissue, light delivery devices can be placed farther from neurons expressing these red-shifted opsins, in some cases even outside the brain entirely.

\section{Channel and pump activity}

There are many ways in which opsin-mediated neural events may potentially differ from those mediated by natural input. Compared with electrical stimulation, many opsins conduct for longer periods of time, due to the intrinsic kinetics of the channels. Slow depolarizations resulting from optogenetic drive may engage endogenous ion channels, resulting for example in calcium entry through voltage-gated calcium channels (Zhang and Oertner 2006). Prolonged channelrhodopsin-mediated depolarization can also result in depolarization block, a phenomenon in which pulses of light of sufficient duration inhibit action potential firing by causing sodium channel inactivation (Herman et al. 2014). Conversely, the hyperpolarization mediated by silencing opsins can engage hyperpolarization-activated channels (e.g., $\mathrm{I}_{\mathrm{h}}$ nonspecific cation channels, T-type calcium channels), resulting sometimes in "rebound" action potentials (seen in many papers using either chloride pumps, proton pumps, or electrical stimulation for hyperpolarization, e.g., Madisen et al. 2012), which can be reduced by sculpting the waveform of the light so that such channels are not engaged (Chuong et al. 2014). All opsins exhibit some degree of desensitization during long periods of illumination, which is a function of the brightness and color of 
the light delivered; it is important to validate, especially for long duration light stimuli, the efficacy of the opsin throughout the experimental timecourse.

Beyond direct voltage driven effects, the specific ions conducted through optogenetic tools may alter neural functions via their interactions with signaling molecules. For example, channelrhodopsins pass multiple species of cation, chiefly protons and sodium, but also calcium and potassium (Nagel et al. 2003). Halorhodopsins and archaerhodopsins actively pump chloride into cells (Han and Boyden 2007; Zhang et al. 2007a) and protons out of cells (Chow et al. 2010), respectively. All of these ions in principle can modulate cellular functions. Calcium has a signaling role in many aspects of cellular physiology, ranging from synaptic plasticity to apoptosis to gene expression (Berridge et al. 2000). It has been reported that channelrhodopsin-mediated calcium entry (using the molecule CatCh, which was engineered toward the goal of higher calcium flux [Kleinlogel et al. 2011]) through the plasma membrane enhances the function of voltage-gated sodium channels, and thus increases neural excitability. Halorhodopsins can pump enough chloride into cells to alter the reversal potential of GABA receptors (Raimondo et al. 2012). Channelrhodopsins expressed in Bergmann glia in cerebellar slices, upon illumination, drive glutamate release, most likely through intracellular acidification (Beppu et al. 2014). In the same preparation, light-driven proton pumps expressed in Bergmann glia could prevent ischemic brain damage, perhaps due to alkalinization of the cells and suppression of glutamate release.

Opsins may also be able to exert their voltage-dependent and ion-dependent signals in intracellular organelles, whether naturally or deliberately targeted there. Glial cells in culture or in visual cortex slices, expressing channelrhodopsin-2, release calcium from intracellular stores upon illumination (Figueiredo et al. 2014; Perea et al. 2014), as evidenced by the blockade of opsin-mediated calcium signals when such stores are depleted with the drug thapsigargin. Deliberately targeting proton pumps to mitochondria of yeast or mammalian cells has been reported to result in cell survival with less reliance on oxidative phosphorylation (Hoffmann et al. 1994; Hara et al. 2013). Thus, optogenetic tools may be utilized to study the effects of specific ions on specific physiological processes. If side effects from the ions conducted by specific opsins are a concern, one useful strategy is to use multiple opsins that result in similar voltage effects, but rely on different ionic species (Adesnik et al. 2012; Stefanik et al. 2012; Kimura et al. 2013).

\section{Network-level side effects}

Because neurons are connected-via synapses, gap junctions, and other interfaces-perturbation of the activity of a cell or set of cells can impact the activity of downstream neurons. While assessing the contribution of a cell or set of cells to network function is of course one of the key uses for optogenetics, activating or silencing a cell or set of cells may cause multiple effects, some of which are not understood or desired. Here we describe some examples of potentially unintended network side effects of the optical perturbation of a set of cells.

On short timescales, manipulating neural activity can lead to network effects like altering the balance of excitation and inhibition. For example, silencing a set of tonically active neurons may deprive downstream regions of input necessary to keep their basal activity levels within the normal dynamic range of operation (e.g., Bao et al. 2002). Experimentally activating or silencing a set of neurons may result in downstream circuits being driven or deprived of activity in ways that do not occur endogenously. This is especially true if an entire population is being synchronously activated or silenced. Activating a set of excitatory neurons could recruit inhibitory neurons that then silence excitatory neurons, perhaps even some of the same ones that were excited by light (Han et al. 2009). Optogenetic silencing of excitatory neurons that drive inhibitory neurons could result in disinhibition of the neurons targeted by the inhibitory neurons (Han et al. 2011), with analogous possibilities for the case of silencing inhibitory neurons (Witten et al. 2010). While these phenomena reflect the action of circuits that exist in a normally functioning brain, they should be taken into account when interpreting the behavioral impact of an optogenetic perturbation.

Plasticity and homeostatic adaptation can also result from perturbations of neural activity. Long-term potentiation, an increase in the synaptic efficacy between neurons, may be induced with presynaptic excitation and postsynaptic channelrhodopsin activation through as few as 20 pairings (Zhang and Oertner 2006). Other changes-including homeostatic plasticity (Turrigiano et al. 1998; Borodinsky et al. 2004; Thiagarajan et al. 2005; Hnasko and Edwards 2012), changes in synaptic function due to retrograde cannabinoid signaling (Kreitzer and Regehr 2001; Wilson and Nicoll 2001), nitric oxide signaling (Lev-Ram et al. 1995), and many other mechanisms that can cause side effects may also be engaged, since they are downstream of neural activation. As described above, these phenomena may be either bugs or features in experiments, depending on how they are interpreted and whether they can reveal new findings in a wellcontrolled way. For example, optogenetic silencing of the CA1 region of the hippocampus for $30 \mathrm{~min}$ can lead to recruitment of another brain region-the anterior cingulate-to help animals remember what contexts to fear, though such recruitment of the anterior cingulate does not occur with brief optogenetic silencing (Goshen et al. 2011), potentially implicating a role for network homeostatic plasticity in memory.

Even over short timescales, optogenetic perturbation can cause recruitment of undesired targets if the photostimulated neurons project to multiple regions. Optogenetic stimulation of axons projecting to one region may result in action potentials that backpropagate to the cell body and also end up driving other, undesired regions. Careful tracing of the anatomy of the cells of the targeted axons, i.e., through retrograde viral techniques, may alleviate this concern if it reveals that the neurons in question project only to the desired region (Betley et al. 2013; Stamatakis et al. 2013). When this approach is either untenable or reveals collateral axons to multiple brain regions, one can silence the cell body (e.g., pharmacologically) while stimulating the axon terminals (Stuber et al. 2011), but of course this also alters any computations that depend on the cell body. One can also infuse the target region of the projection with a neurotransmitter antagonist, to test whether the behavioral effect of optogenetic stimulation of the projections is abolished (Tye et al. 2011). The multiplexed usage of single neurons to control multiple targets has behavioral as well as physiological consequences. For example, inhibition of serotonin neurons or Purkinje cell activity via optogenetic or chemogenetic means can alter core body temperature or blood pressure (Ray et al. 2011; Tsubota et al. 2012), revealing new functions not widely thought of as being associated with these cell types.

To monitor network effects of optogenetic manipulation, careful observation of network activity is crucial. Neural recordings can confirm that optogenetic manipulations are altering activity as intended or can reveal how that activity is altered in unexpected ways. Ideally one would record all possible effects, from changes in intracellular signaling to changes in spike output, in all cells in the nervous system (Marblestone et al. 2013). While this is not currently possible, the development of new technologies, from high-density neural recordings (Berényi et al. 2014; Scholvin et al. 2015) to genetic reporters of activity (Chen et al. 
2013) to new microscopy methods (Prevedel et al. 2014), may help us approach this ideal. In addition, optogenetic manipulations that are even more precise, from opsins that target specific cell compartments to light delivery systems that drive more naturalistic patterns of activity, may both reduce unintended network side effects and reveal how more specific or complex patterns of activity alter the network. For instance, two-photon holographic excitation of opsin-expressing neurons may support manipulation of activity with near-single cell resolution (Andrasfalvy et al. 2010; Papagiakoumou et al. 2010; Packer et al. 2012, 2015). In sum, while optogenetic tools allow for the temporally and spatially precise recruitment of well-defined sets of cells, these tools may lead to potential confounds due to protein expression, ions conducted, heat and light, and network effects. Many of these concerns also apply to other causal technologies, such as chemogenetic inhibition of neurons, pharmacology, and electrical stimulation. Here we have discussed both potential confounds of optogenetic methods and several approaches for addressing these confounds using currently available methods. Future developments will allow for more precise and complex manipulations and observations of neural circuits.

\section{Acknowledgments}

We thank the Boyden laboratory for helpful discussions, and particularly Amy Chuong and Giovanni Talei Franzesi for useful comments and advice on the manuscript. E.S.B. acknowledges funding from the MIT Media Lab, the MIT Synthetic Intelligence Project, the NIH Director's Pioneer Award 1DP1NS087724, and NIH grants 1R01DA029639 and 2R44NS070453.

\section{References}

Adesnik H, Bruns W, Taniguchi H, Huang ZJ, Scanziani M. 2012. A neural circuit for spatial summation in visual cortex. Nature 490: 226-231.

Andrasfalvy BK, Zemelman BV, Tang J, Vaziri A. 2010. Two-photon single-cell optogenetic control of neuronal activity by sculpted light. Proc Natl Acad Sci 107: 11981-11986.

Aponte Y, Atasoy D, Sternson SM. 2011. AGRP neurons are sufficient to orchestrate feeding behavior rapidly and without training. Nat Neurosci 14: $351-355$.

Arenkiel BR, Peca J, Davison IG, Feliciano C, Deisseroth K, Augustine GJ, Ehlers MD, Feng G. 2007. In vivo light-induced activation of neural circuitry in transgenic mice expressing channelrhodopsin-2. Neuron 54: $205-218$.

Arrenberg AB, Del Bene F, Baier H. 2009. Optical control of zebrafish behavior with halorhodopsin. Proc Natl Acad Sci 106: 17968-17973.

Arrenberg AB, Stainier DYR, Baier H, Huisken J. 2010. Optogenetic control of cardiac function. Science 330: 971-974.

Atasoy D, Aponte Y, Su HH, Sternson SM. 2008. A FLEX switch targets channelrhodopsin-2 to multiple cell types for imaging and long-range circuit mapping. J Neurosci 28: 7025-7030.

Ayling OG, Harrison TC, Boyd JD, Goroshkov A, Murphy TH. 2009. Automated light-based mapping of motor cortex by photoactivation of channelrhodopsin-2 transgenic mice. Nat Methods 6: 219-224.

Baier H, Scott EK. 2009. Genetic and optical targeting of neural circuits and behavior-zebrafish in the spotlight. Curr Opin Neurobiol 19: 553-560.

Bamann C, Gueta R, Kleinlogel S, Nagel G, Bamberg E. 2010. Structural guidance of the photocycle of channelrhodopsin- 2 by an interhelical hydrogen bond. Biochemistry 49: 267-278.

Bao S, Chen L, Kim JJ, Thompson RF. 2002. Cerebellar cortical inhibition and classical eyeblink conditioning. Proc Natl Acad Sci 99: 1592-1597.

Beppu K, Sasaki T, Tanaka KF, Yamanaka A, Fukazawa Y, Shigemoto R, Matsui K. 2014. Optogenetic countering of glial acidosis suppresses glial glutamate release and ischemic brain damage. Neuron 81: 314-320.

Berényi A, Somogyvári Z, Nagy AJ, Roux L, Long JD, Fujisawa S, Stark E, Leonardo A, Harris TD, Buzsaki G. 2014. Large-scale, high-density (up to 512 channels) recording of local circuits in behaving animals. J Neurophysiol 111: 1132-1149.

Berndt A, Yizhar O, Gunaydin LA, Hegemann P, Deisseroth K. 2009. Bi-stable neural state switches. Nat Neurosci 12: 229-234.

Bernstein JG, Boyden ES. 2011. Optogenetic tools for analyzing the neural circuits of behavior. Trends Cogn Sci 15: 592-600.
Berridge MJ, Lipp P, Bootman MD. 2000. The versatility and universality of calcium signalling. Nat Rev Mol Cell Biol 1: 11-21.

Betley JN, Sternson SM. 2011. Adeno-associated viral vectors for mapping, monitoring, and manipulating neural circuits. Hum Gene Ther 22: $669-677$.

Betley JN, Cao ZF, Ritola KD, Sternson SM. 2013. Parallel, redundant circuit organization for homeostatic control of feeding behavior. Cell 155: $1337-1350$

Betz UA, Vosshenrich CA, Rajewsky K, Müller W. 1996. Bypass of lethality with mosaic mice generated by Cre-loxP-mediated recombination. Curr Biol 6: 1307-1316.

Bhatla N, Horvitz HR. 2015. Light and hydrogen peroxide inhibit C. elegans feeding through gustatory receptor orthologs and pharyngeal neurons. Neuron 85: 804-818.

Blackshaw S, Snyder SH. 1999. Encephalopsin: A novel mammalian extraretinal opsin discretely localized in the brain. J Neurosci 19: 3681-3690.

Borgius L, Restrepo CE, Leao RN, Saleh N, Kiehn O. 2010. A transgenic mouse line for molecular genetic analysis of excitatory glutamatergic neurons. Mol Cell Neurosci 45: 245-257.

Borodinsky LN, Root CM, Cronin JA, Sann SB, Gu X, Spitzer NC. 2004. Activity-dependent homeostatic specification of transmitter expression in embryonic neurons. Nature 429: 523-530.

Boyden ES. 2011. A history of optogenetics: The development of tools for controlling brain circuits with light. F1000 Biol Rep 3: 11 .

Boyden ES, Zhang F, Bamberg E, Nagel G, Deisseroth K. 2005. Millisecond-timescale, genetically targeted optical control of neural activity. Nat Neurosci 8: 1263-1268.

Bundschuh ST, Zhu P, Schärer YPZ, Friedrich RW. 2012. Dopaminergic modulation of mitral cells and odor responses in the zebrafish olfactory bulb. J Neurosci 32: 6830-6840.

Chen TW, Wardill TJ, Sun Y, Pulver SR, Renninger SL, Baohan A, Schreiter ER, Kerr RA, Orger MB, Jayaraman V, et al. 2013. Ultrasensitive fluorescent proteins for imaging neuronal activity. Nature 499: 295-300.

Chow BY, Boyden ES. 2013. Optogenetics and translational medicine. Sci Transl Med 5: 177ps5.

Chow BY, Han X, Dobry AS, Qian X, Chuong AS, Li M, Henninger MA, Belfort GM, Lin Y, Monahan PE, et al. 2010. High-performance genetically targetable optical neural silencing by light-driven proton pumps. Nature 463: $98-102$.

Christie IN, Wells JA, Southern P, Marina N, Kasparov S, Gourine AV, Lythgoe MF. 2013. fMRI response to blue light delivery in the naïve brain: implications for combined optogenetic fMRI studies. NeuroImage 66: $634-641$.

Chuong AS, Miri ML, Busskamp V, Matthews GA, Acker LC, Sørensen AT, Young A, Klapoetke NC, Henninger MA, Kodandaramaiah SB, et al. 2014. Noninvasive optical inhibition with a red-shifted microbial rhodopsin. Nat Neurosci 17: 1123-1129.

Ciocchi S, Herry C, Grenier F, Wolff SB, Letzkus JJ, Vlachos I, Ehrlich I, Sprengel R, Deisseroth K, Stadler MB, et al. 2010. Encoding of conditioned fear in central amygdala inhibitory circuits. Nature 468: $277-282$.

Desai M, Kahn I, Knoblich U, Bernstein J, Atallah H, Yang A, Kopell N, Buckner RL, Graybiel AM, Moore CI, et al. 2011. Mapping brain networks in awake mice using combined optical neural control and fMRI. J Neurophysiol 105: 1393-1405.

Dittgen T, Nimmerjahn A, Komai S, Licznerski P, Waters J, Margrie TW, Helmchen F, Denk W, Brecht M, Osten P. 2004. Lentivirus-based genetic manipulations of cortical neurons and their optical and electrophysiological monitoring in vivo. Proc Natl Acad Sci 101: 18206-18211.

Doroudchi MM, Greenberg KP, Liu J, Silka KA, Boyden ES, Lockridge JA, Arman AC, Janani R, Boye SE, Boye SL, et al. 2011. Virally delivered channelrhodopsin-2 safely and effectively restores visual function in multiple mouse models of blindness. Mol Ther 19: 1220-1229.

Douglass AD, Kraves S, Deisseroth K, Schier AF, Engert F. 2008. Escape behavior elicited by single, channelrhodopsin-2-evoked spikes in zebrafish somatosensory neurons. Curr Biol 18: 1133-1137.

Edwards SL, Charlie NK, Milfort MC, Brown BS, Gravlin CN, Knecht JE, Miller KG. 2008. A novel molecular solution for ultraviolet light detection in Caenorhabditis elegans. PLoS Biol 6: e198.

Elias Z, Powers SK, Atstupenas E, Brown JT. 1987. Hyperthermia from interstitial laser irradiation in normal rat brain. Lasers Surg Med 7: $370-375$.

Felix-Ortiz AC, Beyeler A, Seo C, Leppla CA, Wildes CP, Tye KM. 2013. BLA to vHPC inputs modulate anxiety-related behaviors. Neuron 79: $658-664$

Fenno LE, Mattis J, Ramakrishnan C, Hyun M, Lee SY, He M, Tucciarone J, Selimbeyoglu A, Berndt A, Grosenick L, et al. 2014. Targeting cells with single vectors using multiple-feature Boolean logic. Nat Methods 11: $763-772$. 
Figueiredo M, Lane S, Stout RF Jr, Liu B, Parpura V, Teschemacher AG, Kasparov S. 2014. Comparative analysis of optogenetic actuators in cultured astrocytes. Cell Calcium 56: 208-214.

Godsil BP, Fanselow MS. 2004. Light stimulus change evokes an activity response in the rat. Learn Behav 32: 299-310.

Gong S, Zheng C, Doughty ML, Losos K, Didkovsky N, Schambra UB, Nowak NJ, Joyner A, Leblanc G, Hatten ME, et al. 2003. A gene expression atlas of the central nervous system based on bacterial artificial chromosomes. Nature 425: 917-925.

Gong S, Doughty M, Harbaugh CR, Cummins A, Hatten ME, Heintz N, Gerfen CR. 2007. Targeting Cre recombinase to specific neuron populations with bacterial artificial chromosome constructs. J Neurosci 27: $9817-9823$.

Goshen I, Brodsky M, Prakash R, Wallace J, Gradinaru V, Ramakrishnan C, Deisseroth K. 2011. Dynamics of retrieval strategies for remote memories. Cell 147: 678-689.

Gradinaru V, Thompson KR, Zhang F, Mogri M, Kay K, Schneider MB, Deisseroth K. 2007. Targeting and readout strategies for fast optical neural control in vitro and in vivo. J Neurosci 27: 14231-14238.

Gradinaru V, Thompson KR, Deisseroth K. 2008. eNpHR: A Natronomonas halorhodopsin enhanced for optogenetic applications. Brain Cell Biol 36: $129-139$.

Gradinaru V, Zhang F, Ramakrishnan C, Mattis J, Prakash R, Diester I, Goshen I, Thompson KR, Deisseroth K. 2010. Molecular and cellular approaches for diversifying and extending optogenetics. Cell 141: $154-165$.

Han X, Boyden ES. 2007. Multiple-color optical activation, silencing, and desynchronization of neural activity, with single-spike temporal resolution. PLoS One 2: e299.

Han X, Qian X, Bernstein JG, Zhou H, Franzesi GT, Stern P, Bronson RT, Graybiel AM, Desimone R, Boyden ES. 2009. Millisecond-timescale optical control of neural dynamics in the nonhuman primate brain. Neuron 62: 191-198.

Han X, Chow BY, Zhou H, Klapoetke NC, Chuong A, Rajimehr R, Yang A, Baratta MV, Winkle J, Desimone R, et al. 2011. A high-light sensitivity optical neural silencer: development and application to optogenetic control of non-human primate cortex. Front Syst Neurosci 5: 18.

Hara KY, Wada T, Kino K, Asahi T, Sawamura N. 2013. Construction of photoenergetic mitochondria in cultured mammalian cells. Sci Rep 3: 1635 .

Herman AM, Huang L, Murphey DK, Garcia I, Arenkiel BR. 2014. Cell type-specific and time-dependent light exposure contribute to silencing in neurons expressing Channelrhodopsin-2. Elife 3: e01481.

Hnasko TS, Edwards RH. 2012. Neurotransmitter corelease: mechanism and physiological role. Annu Rev Physiol 74: 225-243.

Hoffmann A, Hildebrandt V, Heberle J, Büldt G. 1994. Photoactive mitochondria: in vivo transfer of a light-driven proton pump into the inner mitochondrial membrane of Schizosaccharomyces pombe. Proc Natl Acad Sci 91: 9367-9371.

Huber D, Petreanu L, Ghitani N, Ranade S, Hromádka T, Mainen Z, Svoboda K. 2008. Sparse optical microstimulation in barrel cortex drives learned behaviour in freely moving mice. Nature 451: 61-64.

Inada K, Kohsaka H, Takasu E, Matsunaga T, Nose A. 2011. Optical dissection of neural circuits responsible for Drosophila larval locomotion with halorhodopsin. PLoS One 6: e29019.

Ishizuka T, Kakuda M, Araki R, Yawo H. 2006. Kinetic evaluation of photosensitivity in genetically engineered neurons expressing green algae light-gated channels. Neurosci Res 54: 85-94.

Kalmbach AS, Waters J. 2012. Brain surface temperature under a craniotomy. J Neurophysiol 108: 3138-3146.

Kalmbach A, Hedrick T, Waters J. 2012. Selective optogenetic stimulation of cholinergic axons in neocortex. J Neurophysiol 107: 2008-2019.

Kim KM, Baratta MV, Yang A, Lee D, Boyden ES, Fiorillo CD. 2012. Optogenetic mimicry of the transient activation of dopamine neurons by natural reward is sufficient for operant reinforcement. PLoS One 7: e33612.

Kim SY, Adhikari A, Lee SY, Marshel JH, Kim CK, Mallory CS, Lo M, Pak S, Mattis J, Lim BK, et al. 2013. Diverging neural pathways assemble a behavioural state from separable features in anxiety. Nature 496: 219-223.

Kimura Y, Satou C, Fujioka S, Shoji W, Umeda K, Ishizuka T, Yawo H, Higashijima S. 2013. Hindbrain V2a neurons in the excitation of spinal locomotor circuits during zebrafish swimming. Curr Biol 23: 843-849.

Klapoetke NC, Murata Y, Kim SS, Pulver SR, Birdsey-Benson A, Cho YK, Morimoto TK, Chuong AS, Carpenter EJ, Tian Z, et al. 2014. Independent optical excitation of distinct neural populations. Nat Methods 11: 338-346.

Klein R, Dayton R, Leidenheimer N, Jansen K, Golde T, Zweig R. 2006. Efficient neuronal gene transfer with AAV8 leads to neurotoxic levels of $\tau$ or green fluorescent proteins. Mol Ther 13: 517-527.

Kleinlogel S, Feldbauer K, Dempski RE, Fotis H, Wood PG, Bamann C, Bamberg E. 2011. Ultra light-sensitive and fast neuronal activation with the $\mathrm{Ca}^{2+}$-permeable channelrhodopsin CatCh. Nat Neurosci 14: $513-518$

Kocabas A, Shen CH, Guo ZV, Ramanathan S. 2012. Controlling interneuron activity in Caenorhabditis elegans to evoke chemotactic behaviour. Nature 490: 273-277.

Kolisnyk B, Guzman MS, Raulic S, Fan J, Magalhães AC, Feng G, Gros R, Prado VF, Prado MA. 2013. ChAT-ChR2-EYFP mice have enhanced motor endurance but show deficits in attention and several additional cognitive domains. J Neurosci 33: 10427-10438.

Koyanagi M, Takada E, Nagata T, Tsukamoto H, Terakita A. 2013. Homologs of vertebrate Opn3 potentially serve as a light sensor in nonphotoreceptive tissue. Proc Natl Acad Sci 110: 4998-5003.

Kreitzer AC, Regehr WG. 2001. Retrograde inhibition of presynaptic calcium influx by endogenous cannabinoids at excitatory synapses onto Purkinje cells. Neuron 29: 717-727.

Kügler S, Lingor P, Schöll U, Zolotukhin S, Bähr M. 2003. Differential transgene expression in brain cells in vivo and in vitro from AAV-2 vectors with small transcriptional control units. Virology 311: 89-95.

Kuhlman SJ, Huang ZJ. 2008. High-resolution labeling and functional manipulation of specific neuron types in mouse brain by Cre-activated viral gene expression. PLoS One 3: e2005.

Lev-Ram V, Makings LR, Keitz PF, Kao JP, Tsien RY. 1995. Long-term depression in cerebellar Purkinje neurons results from coincidence of nitric oxide and depolarization-induced $\mathrm{Ca}^{2+}$ transients. Neuron 15: $407-415$.

Liu HS, Jan MS, Chou CK, Chen PH, Ke NJ. 1999. Is green fluorescent protein toxic to the living cells? Biochem Biophys Res Commun 260: $712-717$.

Liu J, Ward A, Gao J, Dong Y, Nishio N, Inada H, Kang L, Yu Y, Ma D, Xu T, et al. 2010. C. elegans phototransduction requires a $G$ proteindependent cGMP pathway and a taste receptor homolog. Nat Neurosci 13: $715-722$.

Long MA, Fee MS. 2008. Using temperature to analyse temporal dynamics in the songbird motor pathway. Nature 456: 189-194.

Madisen L, Mao T, Koch H, Zhuo J, Berenyi A, Fujisawa S, Hsu YW, Garcia AJ III, Gu X, Zanella S, et al. 2012. A toolbox of Cre-dependent optogenetic transgenic mice for light-induced activation and silencing. Nat Neurosci 15: $793-802$.

Marblestone AH, Zamft BM, Maguire YG, Shapiro MG, Cybulski TR, Glaser JI, Amodei D, Stranges PB, Kalhor R, Dalrymple DA, et al. 2013. Physical principles for scalable neural recording. Front Comput Neurosci 7: 137.

Metzger D, Feil R. 1999. Engineering the mouse genome by site-specific recombination. Curr Opin Biotechnol 10: 470-476.

Miyashita T, Shao YR, Chung J, Pourzia O, Feldman DE. 2013. Long-term channelrhodopsin-2 (ChR2) expression can induce abnormal axonal morphology and targeting in cerebral cortex. Front Neural Circuits 7: 8 .

Moser E, Mathiesen I, Andersen P. 1993. Association between brain temperature and dentate field potentials in exploring and swimming rats. Science 259: 1324-1326.

Nagel G, Szellas T, Huhn W, Kateriya S, Adeishvili N, Berthold P, Ollig D, Hegemann P, Bamberg E. 2003. Channelrhodopsin-2, a directly light-gated cation-selective membrane channel. Proc Natl Acad Sci 100: $13940-13945$.

Nagel G, Brauner M, Liewald JF, Adeishvili N, Bamberg E, Gottschalk A. 2005. Light activation of channelrhodopsin-2 in excitable cells of Caenorhabditis elegans triggers rapid behavioral responses. Curr Biol 15: 2279-2284.

Nathanson JL, Yanagawa Y, Obata K, Callaway EM. 2009. Preferential labeling of inhibitory and excitatory cortical neurons by endogenous tropism of adeno-associated virus and lentivirus vectors. Neuroscience 161: $441-450$.

Oh SW, Harris JA, Ng L, Winslow B, Cain N, Mihalas S, Wang Q, Lau C, Kuan L, Henry AM, et al. 2014. A mesoscale connectome of the mouse brain. Nature 508: 207-214.

Okano T, Yoshizawa T, Fukada Y. 1994. Pinopsin is a chicken pineal photoreceptive molecule. Nature 372: 94-97.

Packer AM, Peterka DS, Hirtz JJ, Prakash R, Deisseroth K, Yuste R. 2012. Two-photon optogenetics of dendritic spines and neural circuits. Nat Methods 9: 1202-1205.

Packer AM, Russell LE, Dalgleish HW, Häusser M. 2015. Simultaneous all-optical manipulation and recording of neural circuit activity with cellular resolution in vivo. Nat Methods 12: 140-146.

Papagiakoumou E, Anselmi F, Bègue A, de Sars V, Glückstad J, Isacoff EY, Emiliani V. 2010. Scanless two-photon excitation of channelrhodopsin-2. Nat Methods 7: 848-854.

Perea G, Yang A, Boyden ES, Sur M. 2014. Optogenetic astrocyte activation modulates response selectivity of visual cortex neurons in vivo. Nat Commun 5: 3262.

Prevedel R, Yoon YG, Hoffmann M, Pak N, Wetzstein G, Kato S, Schrödel T, Raskar R, Zimmer M, Boyden ES, et al. 2014. Simultaneous 
whole-animal 3D imaging of neuronal activity using light-field microscopy. Nat Methods 11: 727-730.

Raimondo JV, Kay L, Ellender TJ, Akerman CJ. 2012. Optogenetic silencing strategies differ in their effects on inhibitory synaptic transmission. Nat Neurosci 15: 1102-1104.

Ray RS, Corcoran AE, Brust RD, Kim JC, Richerson GB, Nattie E, Dymecki SM. 2011. Impaired respiratory and body temperature control upon acute serotonergic neuron inhibition. Science 333: 637-642.

Schmitt C, Schultheis C, Pokala N, Husson SJ, Liewald JF, Bargmann CI, Gottschalk A. 2012. Specific expression of channelrhodopsin-2 in single neurons of Caenorhabditis elegans. PLoS One 7: e43164.

Scholvin J, Kinney JP, Bernstein JG, Moore-Kochlacs C, Kopell N, Fonstad CG, Boyden ES. 2015. Close-packed silicon microelectrodes for scalable spatially oversampled neural recording. IEEE Trans Biomed Eng. doi: 10.1109/TBME.2015.2406113.

Schroll C, Riemensperger T, Bucher D, Ehmer J, Völler T, Erbguth K, Gerber B, Hendel T, Nagel G, Buchner E, et al. 2006. Light-induced activation of distinct modulatory neurons triggers appetitive or aversive learning in Drosophila larvae. Curr Biol 16: 1741-1747.

Shapiro MG, Frazier SJ, Lester HA. 2012. Unparalleled control of neural activity using orthogonal pharmacogenetics. ACS Chem Neurosci 3: $619-629$.

Sohal VS, Zhang F, Yizhar O, Deisseroth K. 2009. Parvalbumin neurons and $\gamma$ rhythms enhance cortical circuit performance. Nature 459: 698-702.

Stamatakis AM, Jennings JH, Ung RL, Blair GA, Weinberg RJ, Neve RL Boyce F, Mattis J, Ramakrishnan C, Deisseroth K, et al. 2013. A unique population of ventral tegmental area neurons inhibits the lateral habenula to promote reward. Neuron 80: 1039-1053.

Stefanik MT, Moussawi K, Kupchik YM, Smith KC, Miller RL, Huff ML, Deisseroth K, Kalivas PW, LaLumiere RT. 2012. Optogenetic inhibition of cocaine seeking in rats. Addict Biol 18: 50-53.

Stuber GD, Sparta DR, Stamatakis AM, van Leeuwen WA, Hardjoprajitno JE, Cho S, Tye KM, Kempadoo KA, Zhang F, Deisseroth K, et al. 2011. Excitatory transmission from the amygdala to nucleus accumbens facilitates reward seeking. Nature 475: $377-380$.

Thiagarajan TC, Lindskog M, Tsien RW. 2005. Adaptation to synaptic inactivity in hippocampal neurons. Neuron 47: 725-737.

Toni N, Laplagne DA, Zhao C, Lombardi G, Ribak CE, Gage FH, Schinder AF. 2008. Neurons born in the adult dentate gyrus form functional synapses with target cells. Nat Neurosci 11: 901-907.

Tsubota T, Ohashi Y, Tamura K, Miyashita Y. 2012. Optogenetic inhibition of Purkinje cell activity reveals cerebellar control of blood pressure during postural alterations in anesthetized rats. Neuroscience 210: 137-144.

Tsunematsu T, Kilduff TS, Boyden ES, Takahashi S, Tominaga M, Yamanaka A. 2011. Acute optogenetic silencing of orexin/hypocretin neurons induces slow-wave sleep in mice. J Neurosci 31: 10529-10539.

Turrigiano GG, Leslie KR, Desai NS, Rutherford LC, Nelson SB. 1998. Activity-dependent scaling of quantal amplitude in neocortical neurons. Nature 391: 892-896.

Tye KM, Prakash R, Kim SY, Fenno LE, Grosenick L, Zarabi H, Thompson KR, Gradinaru V, Ramakrishnan C, Deisseroth K. 2011.
Amygdala circuitry mediating reversible and bidirectional control of anxiety. Nature 471: $358-362$.

Wen Q, Po MD, Hulme E, Chen S, Liu X, Kwok SW, Gershow M, Leifer AM, Butler V, Fang-Yen C, et al. 2012. Proprioceptive coupling within motor neurons drives C. elegans forward locomotion. Neuron 76: 750-761.

Wilson RI, Nicoll RA. 2001. Endogenous cannabinoids mediate retrograde signalling at hippocampal synapses. Nature 410: $588-592$.

Witten IB, Lin SC, Brodsky M, Prakash R, Diester I, Anikeeva P, Gradinaru V, Ramakrishnan C, Deisseroth K. 2010. Cholinergic interneurons control local circuit activity and cocaine conditioning. Science 330: $1677-1681$

Xiang Y, Yuan Q, Vogt N, Looger LL, Jan LY, Jan YN. 2010. Light-avoidance-mediating photoreceptors tile the Drosophila larval body wall. Nature 468: 921-926.

Yizhar O, Fenno LE, Prigge M, Schneider F, Davidson TJ, O'Shea DJ, Sohal VS, Goshen I, Finkelstein J, Paz JT, et al. 2011. Neocortica excitation/inhibition balance in information processing and social dysfunction. Nature 477: 171-178.

Zhang YP, Oertner TG. 2006. Optical induction of synaptic plasticity using a light-sensitive channel. Nat Methods 4: 139-141.

Zhang F, Wang LP, Brauner M, Liewald JF, Kay K, Watzke N, Wood PG, Bamberg E, Nagel G, Gottschalk A, et al. 2007a. Multimodal fast optical interrogation of neural circuitry. Nature 446: 633-639.

Zhang W, Ge W, Wang Z. 2007b. A toolbox for light control of Drosophila behaviors through Channelrhodopsin 2-mediated photoactivation of targeted neurons. Eur J Neurosci 26: 2405-2416.

Zhao S, Cunha C, Zhang F, Liu Q, Gloss B, Deisseroth K, Augustine GJ, Feng G. 2008. Improved expression of halorhodopsin for light-induced silencing of neuronal activity. Brain Cell Biol 36: 141-154.

Zhao S, Ting JT, Atallah HE, Qiu L, Tan J, Gloss B, Augustine GJ, Deisseroth K, Luo M, Graybiel AM, et al. 2011. Cell type-specific channelrhodopsin-2 transgenic mice for optogenetic dissection of neural circuitry function. Nat Methods 8: 745-752.

Zhu P, Narita Y, Bundschuh ST, Fajardo O, Schärer YP, Chattopadhyaya B, Bouldoires EA, Stepien AE, Deisseroth K, Arber S, et al. 2009. Optogenetic dissection of neuronal circuits in zebrafish using viral gene transfer and the Tet system. Front Neural Circuits 3: 21.

Zhuang X, Masson J, Gingrich JA, Rayport S, Hen R. 2005. Targeted gene expression in dopamine and serotonin neurons of the mouse brain. J Neurosci Methods 143: 27-32.

Zimmermann D, Zhou A, Kiesel M, Feldbauer K, Terpitz U, Haase W, Schneider-Hohendorf T, Bamberg E, Sukhorukov VL. 2008. Effects on capacitance by overexpression of membrane proteins. Biochem Biophys Res Commun 369: 1022-1026.

Zorzos AN, Boyden ES, Fonstad CG. 2010. Multiwaveguide implantable probe for light delivery to sets of distributed brain targets. Opt Lett 35: $4133-4135$

Received December 30, 2014; accepted in revised form February 13, 2015. 


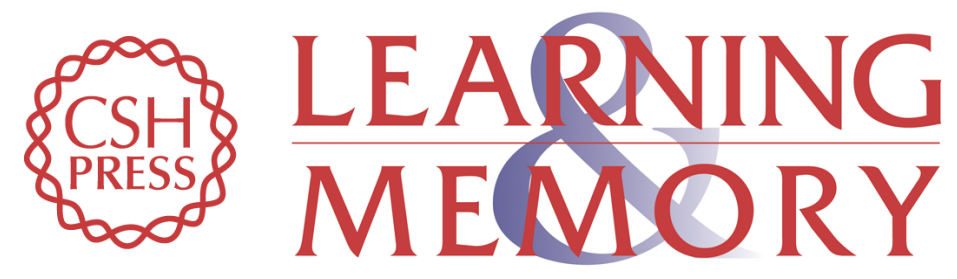

\title{
Principles of designing interpretable optogenetic behavior experiments
}

\author{
Brian D. Allen, Annabelle C. Singer and Edward S. Boyden
}

Learn. Mem. 2015, 22:

Access the most recent version at doi:10.1101/Im.038026.114

$\begin{array}{ll}\text { References } & \text { This article cites } 121 \text { articles, } 19 \text { of which can be accessed free at: } \\ \text { http://learnmem.cshlp.org/content/22/4/232.full.html\#ref-list-1 }\end{array}$

Creative This article, published in Learning \& Memory, is available under a Creative Commons Commons License (Attribution 4.0 International), as described at

License http://creativecommons.org/licenses/by/4.0/. Email Alerting $\begin{aligned} & \text { Receive free email alerts when new articles cite this article - sign up in the box at the } \\ & \text { Service }\end{aligned}$ top right corner of the article or click here. 